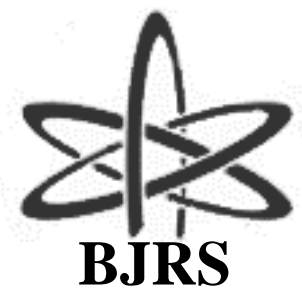

\author{
BRAZILIAN JOURNAL \\ $\mathrm{OF}$ \\ RADIATION SCIENCES \\ 08-03A (2020) 01-13
}

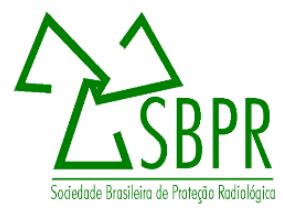

\title{
Technology transfer: the case of the Centro de Desenvolvimento da Tecnologia Nuclear (Nuclear Technology Development Center)
}

\author{
Xênia Aparecida Chaves Santos, Régia Ruth Ramirez Guimarães, Gustavo José \\ Pereira, Sérgio Almeida Cunha Filgueiras \\ Universidade Federal de Minas Gerais \\ xeniasantos89@yahoo.com.br
}

\section{RESUMO}

A transferência de tecnologia faz parte do processo de inovação e tem o papel de contribuir para o desenvolvimento econômico local e nacional. Inserido no âmbito do Sistema Nacional de Inovação, este estudo foi realizado com o objetivo de apresentar como está sendo realizada a transferência de tecnologia no CDTN. A partir de uma pesquisa realizada pelo NIT-CDTN sobre as tecnologias desenvolvidas na instituição, foi elaborado um portfólio de informações importantes sobre as mesmas com o objetivo principal de avaliar essas tecnologias, utilizando o grau de maturidade e o interesse econômico para classificá-las. As tecnologias do CDTN têm um potencial razoável para gerar valor, mas precisam de maturidade tecnológica para alcançar a transferência para o mercado. O estudo realizado pelo NIT-CDTN mostra que o CDTN já possui um bom conjunto de ferramentas para promover a inovação tecnológica de alta qualidade. A escala Technology Readiness Level - TRL (em português : Níveis de Maturidade Tecnológica) foi utilizado para avaliar o nível de maturidade das tecnologias com maior potencial de transferência. Para garantir o sucesso da transferência, é necessário consolidar a metodologia para incluir aspectos-chave como avaliação, pesquisa de mercado e adaptação de metodologias existentes de acordo com a necessidade da instituição e do mercado. Para concluir, percebe-se que o ideal seria investir nas tecnologias mais promissoras para obter um avanço na escala piloto.

Palavras-chave: Transferência de Tecnologia, Inovação Tecnológica, Propriedade Intelectual. 


\begin{abstract}
The technology transfer is part of the innovation process and has the role of contributing to local and national economic development. Inserted within the scope of the National Innovation System, this study was made with the goal of presenting how the technology transfer is being made in the CDTN. Based on a survey carried out by the NIT-CDTN of the technologies developed in the institution, a portfolio of key information about them was made with the main objective of evaluating those technologies, using the degree of maturity and economic interest to classify them. CDTN technologies have a reasonable potential for generating value, yet they need technological maturity to achieve the transfer to the market. The study carried out by NIT-CDTN shows that CDTN already has a good set of tools to promote high quality technological innovation. The TRL (Technology Readiness Level) scale was used to evaluate the maturity level of technologies with higher transfer potential. To ensure the success of the transfer, it is necessary to consolidate the methodology to include key aspects such as valuation, market research and adaptation of existing methodologies according to the need of the institution and the market. To conclude, it is perceived that the ideal would be to invest in the most promising technologies to have a breakthrough for the pilot scale.
\end{abstract}




\section{INTRODUCTION}

Traditionally, scientific researches in Brazil are disseminated through scientific articles. This knowledge, in many cases must be protected as Intellectual Property. Once created, the technologies that are developed in the Science and Technology Institutions (STI or ICTs, in Portuguese abbreviation) can be transfered to the market in order to promote economic and social development, which implies in true structural, cultural and institutional changes [1]. Innovation Management and Technology Transfer are terms that emerged in developed countries in the 1980s and 1990s and were later incorporated into the current scenario of Brazilian STI. In this scenario, the Triple Helix Model proposed by Henry Etzkowitz [2] relates university, government and companies, in order to promote an environment conducive to innovation. The university contributes to the generation of knowledge, to the development of applied research, interacting and striving to adapt its research to the demands of society and the productive sector; companies work in the commercial sphere with the capital and incentive to research; and to the government, it is necessary to articulate and stimulate this integration of university-industry, through laws, fiscal incentives and, mainly, through the financing of basic research. In this context, it is necessary to understand the process of technology transfer, which has the purpose of bringing the knowledge produced by STI to companies, and these, through capital, launch innovative products or processes that will provide advantage in the competitive market [3].

In Brazil, the theme of innovation and technology transfer was highlighted after the creation of the Federal Innovation Law, Law 10,973 / 04, which states in its article 16 on the creation of Nucleus of Technological Innovation (NITs) in the STIs, which are responsible for the management of Intellectual Property and Technology Transfer [3]. The transfer of technology from STI to the productive sector of society can be through: (i) Licensing - guarantees of permission or use of rights of a certain product, industrial design or process; (ii) Publications - articles published in academic journals; (iii) Meetings - face-to-face interaction, in which technical information is exchanged; and (iv) Cooperative R\&D projects - research and development agreements to share people, equipment, intellectual property rights usually between public research institutes and private companies in a research activity. 
Technology transfer between STI and industry is an important part of the innovation process, encompassing a number of activities, which are gaining ground through the establishment of new ideas, and studies aimed at transforming knowledge and technologies into products and / or services for the productive sector. Innovation is a process that also includes social, technological and economic aspects, involving researchers, organizations and the government, in which these different actors must work together towards the development and implementation of new knowledge and the generation of innovation and quality technology.

The STI-industry relationship allows the generation of a virtuous circle that favors innovation, where research and technological development have the objective of promoting a more competitive industrial sector. Academic quality research generates more technological innovations and strengthens the economy for the country. The established link between STI and companies is one of the main means for innovation to happen and allows the National Innovation System (SNI) to evolve [4].

In this context, the Nuclear Technology Development Center (CDTN) appears as an STI that develops several technologies, which may be suitable to investment for use in a consolidated product or process.

\section{THE NUCLEAR TECHNOLOGY DEVELOPMENT CENTER (CDTN)}

The National Nuclear Energy Commission (CNEN) is a federal authority, founded in 1962, through Law No. 4,118 and its purpose is to ensure the development of Brazilian nuclear policy [5]. CNEN is linked to the Ministry of Science, Technology and Innovations (MCTI) and is distributed in nine Brazilian states, with 14 units, including district units, regional offices, laboratories and research institutes, among these last ones, the CDTN.

The CDTN is located in the city of Belo Horizonte / MG and is located on the Federal University of Minas Gerais (UFMG) main campus, occupying an area of $240,000 \mathrm{~m}^{2}$, with a constructed area of $42,000 \mathrm{~m}^{2}$, consisting of 50 laboratories, a nuclear research reactor TRIGA, as well as a Radiopharmaceutical Research and Production Unit, being a medium-sized public STI. The CDTN operates in the areas of Nuclear Technology, Health, Environment, Materials and Mineral Technology. It also works in (i) academic training, with the Masters / Doctorate programs 
recommended by CAPES since 2003 and 2010, respectively; and (ii) provision of technological services.

The Table 1 presents the human capital of the CDTN divided between public sector employees and students who work directly in their lines of research.

Table 1 - Human capital of the Nuclear Technology Development Center.

\begin{tabular}{lclc}
\hline \multicolumn{2}{c}{ Public Sector Employees } & \multicolumn{2}{c}{ Active Collaborators } \\
\hline Researchers & 45 & Master's Degree students & $68(2018)$ \\
Graduate Staff & 70 & PhD students & $60(2018)$ \\
Technicians & 72 & Graduation students & $\sim 100$ \\
Administrative Staff & 74 & Postdoctoral students & $\sim 15$ a 20 \\
Medical Staff & 2 & & \\
Total & $\mathbf{2 6 3}$ & Total & $\mathbf{2 4 8}$ \\
\hline
\end{tabular}

Source: Author.

\section{THE NUCLEUS OF TECHNOLOGICAL INNOVATION OF CDTN}

The management of innovation, intellectual property, technology transfer and other services in this area are done at the Nucleus of Technological Innovation (NIT) of CDTN.

The NIT of the CDTN was created in 2007 in accordance with the attributions of Resolution n. 70, of December 21, 2007, of the CNEN Deliberative Commission. However, the activities of cooperation with companies and the provision of technological services were already made since the 1980s; in the 1990s, the CDTN already had a sector to manage its Intellectual Property and also to formalize academic and company partnerships.

The NIT is composed of a Coordinator, an Intellectual Property Analyst (both public sector employees) and a Level II Science and Technology Management Fellow, supported by the Research Support Foundation of the State of Minas Gerais.

The activities of the NIT in the CDTN take place in the following activities: (i) technology partnership contracts, (ii) technology transfer contracts under research contracts, (iii) confidentiality and secrecy contracts, (iv) Protocol of Intent/Academic Cooperation (v) Ownership sharing as presented in Table 2 and also in the provision of technological services. In addition, it participated 
in the processes of knowledge protection, namely, 23 patent applications and utility models, registry of 16 softwares and 3 brands, as well as consolidated a portfolio of 27 technologies. These activities include the technology transfer proposed by the Innovation Law.

Table 2 - Different modalities of partnerships and respective values obtained in the current projects.

\begin{tabular}{lcr}
\hline Contract modality & $\begin{array}{c}\text { Number of } \\
\text { Contracts }\end{array}$ & Funds obtained (US\$) \\
\hline (i) Technology partnership contracts & 15 & $3,830,000.00$ \\
(ii) Research contract & 4 & $290,000.00$ \\
(iii) Confidentiality and secrecy contracts & 19 & - \\
(iv) Protocol of Intent / Academic Cooperation & 12 & - \\
(v) Ownership sharing & 6 & - \\
Total & $\mathbf{5 3}$ & $\mathbf{4 , 1 2 0 , 0 0 0 . 0 0}$ \\
\hline
\end{tabular}

Source: Autor.

\section{METHODOLOGY}

\subsection{Innovation Diligence}

The methodology used in this work was an adaptation and validation of a methodology called " Innovation Diligence", which was previously used by the company Inventta in providing consultancy at the CDTN in 2011. The results of the consultancy obtained by the company were satisfactory and only disclosed to the CDTN on a mobile device. However, it was necessary to adapt this methodology by inserting step 4.2 shown below and also due to the new technologies included in the STI portfolio.

\subsubsection{Selecting technologies}

At this stage, the technologies developed in the CDTN were evaluated in order to verify which ones are better prepared for the technology transfer process.

\subsubsection{Technological description}


Elaboration of a technological description for each technology in which the NIT team of the CDTN sought each researcher responsible for the technology to collect the necessary information according to the descriptions listed below:

1. Technology Name

2. Technology Description

3. Development Stage and Other Relevant Information

4. Protection by Intellectual Property

5. Leading Researcher and Other Team Researchers

6. Objectives of the Researcher or Research Group

7. Technology Differentials

8. Market Potential

9. Market Problem

10. Proposed Solution

11. Benefits

Interviews were conducted with the researchers to obtain the necessary information. Through these descriptions a summary of the most important information for the basic understanding of the technology is obtained.

\subsubsection{Technology Portfolio}

Creation of a portfolio of online technologies containing the technological descriptions on the CDTN website, in order to allow other partners to have access to the basic information of the technologies for later transfer of technology; 27 technical descriptions were made, referring to the 27 technologies of the CDTN and made available in ".pdf" format on the website of the institution, in the link "Technology Portfolio" in the field of "Technological Innovation". The descriptive aims are to favor the CDTN's partnership with other institutions and companies. 


\subsubsection{Survey}

A survey was made to evaluate the degree of maturity and potential of value creation. The technologies were evaluated through a questionnaire in which scores of 1 to 4 were assigned for each question answered. The questionnaire used was adapted from the criteria of strategic interest of the institution. These criteria measure the stage of development of the technology and its respective value potential. Questions were divided between these criteria and the applied questionnaire is shown below:

\section{X axis - Technology Level of Development}

1. Qualification of the team to manage technological evolution

2. Knowledge of the possible applications of the technological innovation

3. Development process in laboratory and industrial scale

4. Proximity to the start of the marketing of the product

\section{Y axis - Potential of Generation of Economic Value}

1. Existence of problems that can be solved by the technological innovation

2. Comparison of the proposed technological innovation with similar applications

3. Degree of Technological Innovation

4. Assessment of entry barriers.

\subsubsection{Classification}

Classifying and comparing technologies for economic interest and degree of maturity will be the next step.

\subsection{Technology Readiness Level - TRL}

The Technology Readiness Level - TRL was used to evaluate the maturity level of the technologies holding a bigger potential of transference. 
There are several methodologies for evaluating technological maturity, among them the Technology Readiness Level (TRL), which was developed with the purpose of providing a measure regarding the state of a new technology in relation to its use for future space systems. This methodology was consolidated and is of worldwide use and is used to analyze risks inherent to the process of technology development and to provide information for decision making and guidelines for managers in the area of Research, Development and Innovation [6].

\section{RESULTS AND DISCUSSION}

The results obtained are shown in Figure 1. The technologies positioned in the circle highlighted in the graph were considered those with the highest probability of success in the transfer process.

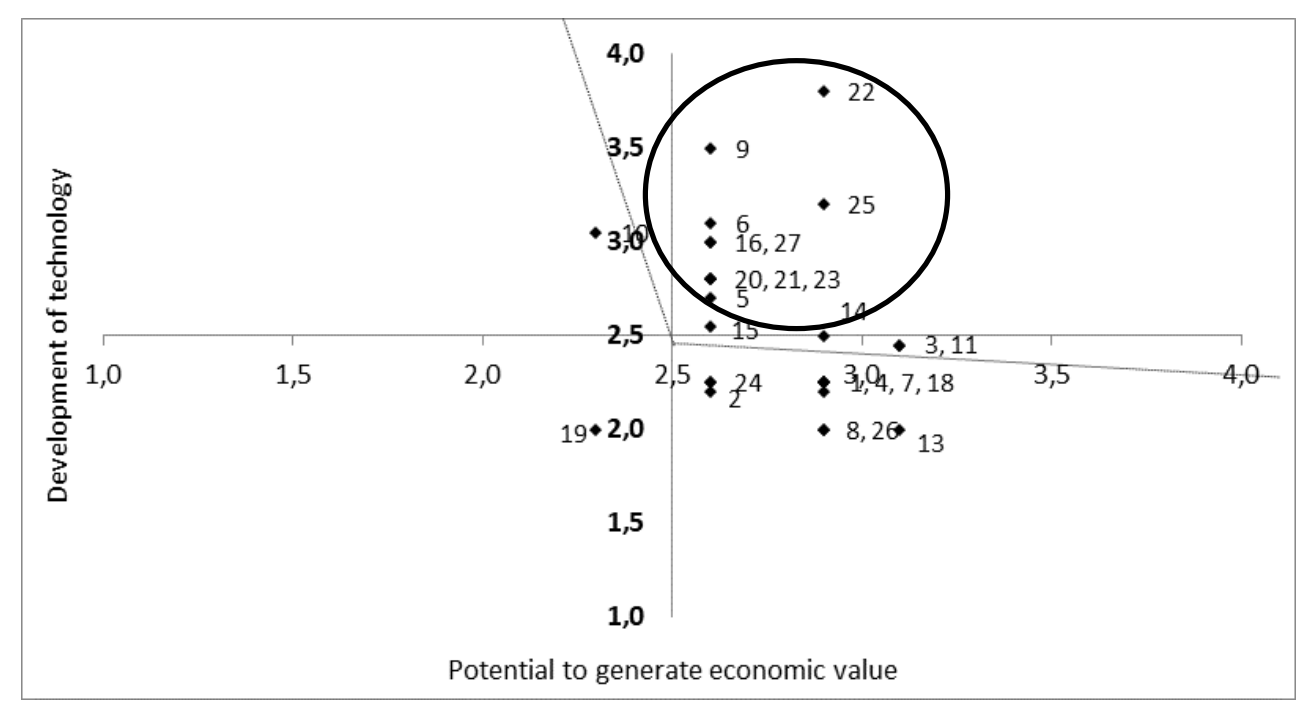

Figure 1 - Prioritization of CDTN Technologies.

The technologies highlighted in the graphic were the prioritized ones, however they need advances in the development.

The TRL scale used to evaluate Technologies, was initially designed in 1974 by Stan Sadin, a NASA researcher [7]. In 1989, this scale was formalized, still with seven readiness levels [8] and in 1995 it was reinforced with two more levels, in a spectrum of one to nine, represented by Figure 2. $[9,10,11]$. 


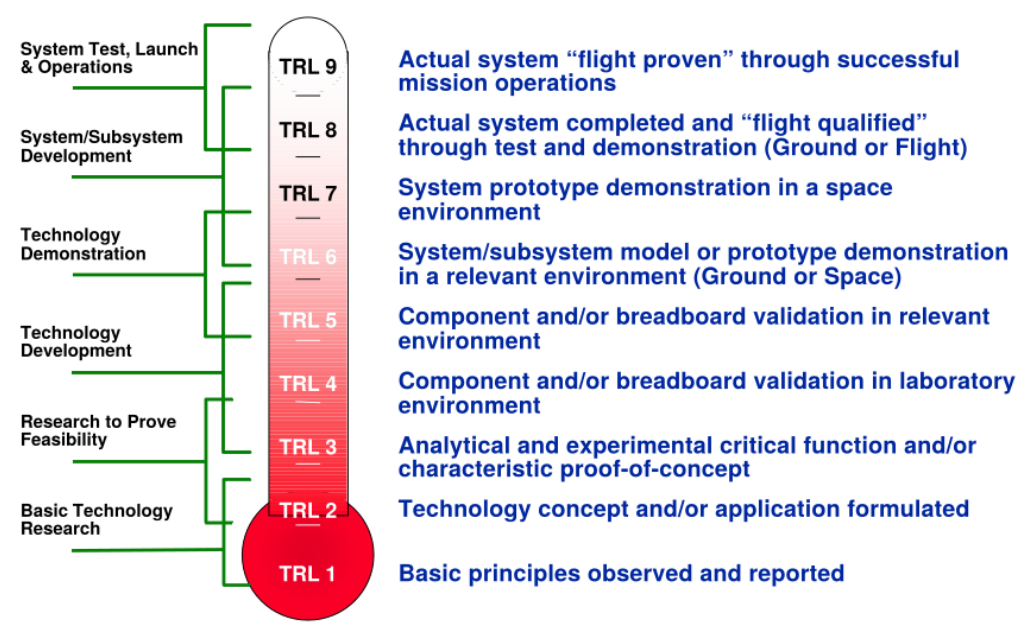

Figure 2 - Scale of technological readiness levels - TRL [11].

According to Quintella (2017) [12], in accordance with the scale of the TRL methodology applied to scientific research, it is possible to describe the levels as follows:

TRL1 to TRL3: basic and partially applied scientific research (abstracts in events, articles, etc.); traditionally referred as bench level technology.

TRL4 to TRL6: technological development focused on applied research and where technology transfer still has great academic bias requiring rounds of negotiation of IP Portfolios and mentoring, startups; traditionally referred to as a pilot, for example.

TRL7 to TRL9: finalization of technologies, with high interaction with incubators, technology parks, startup accelerators etc.; traditionally called a demonstration, and then a commercial one [12].

The methodology of classification of the technologies developed in the institution is consolidated and proved adequate. The results agree with the TRL methodology and the CDTN technologies are between levels 2 and 4 in which the surveys are at bench level. 
The market prospecting phase is being carried out and a valuation methodology is being developed for technologies with a degree of maturity that is not sufficient for direct application. It also needs to be adapted to existing ones by the characteristics of the technologies.

The adherence between the classification methodology used and the TRL allows one to have an idea of the value of the technologies. This is important to base licensing or co-ownership negotiations when developing jointly with companies.

\section{CONCLUSION}

STI is playing an important role in the system of generating innovation environments, whether in staff training or in support of new business creation. The CDTN has the knowledge, teaching and research that can work together to promote innovation.

According to the methodology that was adapted to the institution and given the graph presented, the prioritization of the technologies according to the criteria of degree of development versus economic potential was made. At this stage, it was identified that most of the CDTN technologies are in the pilot phase, which makes it difficult to transfer to the market, looking at the aspect that was outlined through the key questions asked to evaluate the technologies. The ideal scenario would be to invest in the most promising ones to have a breakthrough to the pilot scale.

The process of implementing an effective methodology for technology transfer is still obscured mainly by the lack of entrepreneurial culture in STI. According to Felipe et al. (2018), the case study developed for the performance of the NIT in the CDTN showed a gap in relation to the market prospect of the technologies. What has been done to improve the performance of the same in the institution, is the diffusion of knowledge of technological innovation and intellectual property, through the dissemination of events and workshops of the area using the electronic medium and seminars in the graduate classes. In order to improve the knowledge about valuation and transfer of technology, the NIT team has participated in technological innovation events [12]. 


\section{REFERENCES}

[1] PEREIRA, L. C. B. Crescimento e desenvolvimento econômico. Fundação Getúlio Vargas, p. $1-15,2008$.

[2] ETZKOWITZ, H., LEYDESDORFF, L. The Dynamics of Innovation: from National Systems and "Mode 2" to a Triple Helix of University-Industry-Government Relations, Research Policy, v. 29, p. 109-123, 2000, DOI: 10.1016/S0048-7333(99)00055-4.

[3] CLOSS, L. Q.; FERREIRA G. C. A transferência de tecnologia universidade-empresa no contexto brasileiro: uma revisão de estudos científicos publicados entre os anos 2005 e 2009 , Gestão \& Produção, v. 19, p. 419-432, 2012.

[4] DE CARLI, E.; SEGATTO, A. P.; ALVES, F. S. Capacidades Relacionais na Cooperação Interorganizacional: uma Proposição Teórica, In: XXIX SIMPÓSIO DE GESTÃO DA INOVAÇÃO TECNOLÓGICA, 2016, São Paulo. Annals, 2016.

[5] BRASIL. Lei n. 4.118, de 27 de agosto de 1962. Avaliable at: https://www.planalto.gov.br/ ccivil_03/leis/l.htm. Last accessed: 03 Apr. 2019.

[6] NASA. Technology Readiness Levels Demystified, 2010. Avaliable at: https://www.nasa.gov/topics/aeronautics/features/trl_demystified.html. Last accessed: 26 Jun. 2019.

[7] MORESI, E. A. D.; BARBOSA, J. A.; BRAGA FILHO, M. O. Modelos para analisar níveis de prontidão de inovação, In: SÉPTIMA CONFERENCIA IBEROAMERICANA DE COMPLEJIDAD, INFORMÁTICA Y CIBERNÉTICA - CICIC 2017, 2017, Orlando - FL - USA. Annals 2017, v. 1. p. 78-81.

[8] SADIN S. R.; POVINELLI, F. P.; ROSEN, R. The NASA technology push towards future space mission systems. Acta Astronautica, v. 20, p. 73-77, 1989. 
[9] MANKINS, J. C. Technology Readiness Levels, Office of Space Access and Technology NASA, 1995.

[10] MANKINS, J. C. Technology Readiness Assessments: A Retrospective. Acta Astronautica, v. 65 , p. $1216-1223,2009$.

[11] QUINTELLA, C. M. Revista Cadernos de Prospecção e os níveis de maturidade de tecnologias (TRL). Cadernos de Prospecção, v. 10, n. 1-2, p.1, 2017.

[12] FELIPE, O. L.; PEREIRA, G. J.; GUIMARÃES, R. R. R.; FILGUEIRAS, S. A. C.; SANTOS, X. A. C. "Atuação do Núcleo de Inovação Tecnológica do Centro de Desenvolvimento da Tecnologia Nuclear: um Estudo de Caso. Cadernos de Prospecção, Salvador, v.11, n. 3, p. 813-829, 2018. 